\title{
Change of the Structure of Humus and Microbial Cenoses in Deflated Chestnut Soils
}

\author{
M. G. Merkusheva ${ }^{*}$, S.B. Sosorova \\ Institute of General and Experimental Biology, Siberian Branch of the Russian Academy of Sciences, \\ Ulan-Ude, 670047, Buryatia, Russia \\ *Corresponding Author: merkusheva48@mail.ru, marya.merkuscheva@yandex.ru
}

Copyright (c) 2013 Horizon Research Publishing All rights reserved.

\begin{abstract}
This paper studies the influence exerted by the degradation of dry steppe grasslands and deflation on the content, reserves, and composition of humus in the chestnut soils of Western Transbaikal. In the deflated soils there is a reduction of stocks of humus and its components. Loss of humin acids in the soil contribute to the development fulvatization humus. A decrease of humic compounds depends from the degree of deflation soils. Dehumidification and arenaceous of deflated soils leads to a sharp drop in their fertility, creating a basis for the development movable sands. These negative processes are shown to transform the structure of microbial cenoses and to decrease the enrichment of soils with microorganisms and accumulation of microbial mass in them by changing the soil humus state.
\end{abstract}

Keywords Chestnut Soils Deflation, Humus and its Composition, Structure of Microbe Cenosis, Biological Activity

\section{Introduction}

According to the United Nations, the overall loss of soil cover in the world each year is 7.5 million hectares, and may be increased in the next 25-30 years at 2-3 times.

At present, the area of deflated land in Russia is 7.9 million hectares, or $6.1 \%$ of the arable fund.

The content and reserves of organic matter in soils are a traditional indicator of the fertility and ecological sustainability of soils. The modern state of soils in agricultural lands in the steppe and dry steppe areas of Western Transbaikal should be characterized as dissatisfactory as a result of the broad development of erosion (by water and wind), as well as salinization processes. Deflation is the most widespread in chestnut soils, which are major reserves of grasslands and arable lands that currently cover 343539 ha. The area of mixed deflation and water erosion is also insignificant; it is 180153 ha. The largest centers of the deflation processes in chestnut soils that develop up to the sandy state are in the Barguzin Depression.
Degraded soils are an ecologically dangerous natural object, i.e., they cease to perform the natural and economic functions. The growth in degradation results in the destruction of soil itself as a natural formation and creates significant difficulties for the functioning of other components of ecosystems and natural habitat as a whole [1]. The loss of humus can become ecologically dangerous in the immediate future unless the necessary preventive measures are taken on the global scale, since humus is one of the major solar energy accumulators on the Earth's surface and a guarantee of productivity that ensures the ecological sustainability of the biosphere as a whole [2].

The data on the humus state and microbiological characteristic of the chestnut soils in the Barguzin Depression, including their deflated differences, are very limited [3]. Therefore, the goal of the work was to study the changes in the content, reserves, and composition of humus in the chestnut soils of the Barguzin Depression under dry steppe grasslands and arable lands and structure of their microbial cenoses.

\section{Materials and Methods}

The chestnut soils (grasslands and arable lands) in the Barguzin Depression of Western Transbaikal were the object of studies. The investigations were carried out along the transect from the northwest to the south east of the Upper Kuytun (the Kurumkan Region, Republic of Buryatia) in 1993-2003 (Figure 1).

The content of humus and total nitrogen were determined by the Tyurin method in the Nikitin modification and according to Kjeldahl, respectively $[4,5]$. The group and fractional composition of humus, as well as indicators of the soil humus state, were determined according to Ponomareva and Plotnikova [4] and L.A. Grishina and D.S. Orlov [6], respectively. In order to distinguish different groups of microorganisms and qualitatively take them into account, the following nutrient media were used: bacteria in beef-extract agar (BEA), bacteria and ray fungi in starch-and-ammonia agar (SAA), and fungi in the Chapek medium [7]. A 
microbial biomass was determined according to Zrazhevskii et al. [8]. The biological activity was estimated by the intensity of cellulose decomposition and soil enrichment with microorganisms according to D.G. Zvyagintsev [9].

The stocks of aboveground and underground phytomass in grasslands were taken into account in the first decade of August at the moment of the maximum grass productivity. The results of the investigations were processed by the statistical methods [10].

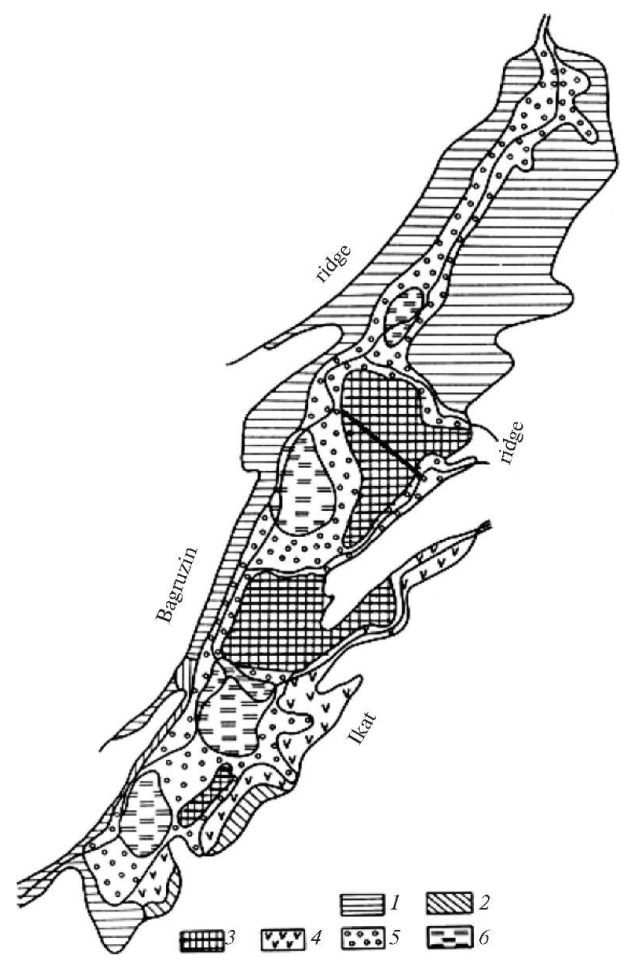

Figure 1. Scheme of vegetation cover in Barguzin Depression (Koposov, Gladkov, 1983). Legend: [-] transects on the Upper Kuytun; vegetation: 1 forests; 2 - forest-steppe; 3 - steppe; 4 - meadow-steppe; 5 - meadow and marshes; 6 - marshes.
The chestnut soils of the Barguzin Depression represent the northernmost area of their expansion $\left(52^{\circ} \mathrm{N}\right)$ and have a number of peculiar natural properties. They function at an average annual temperature of from -3 to $-5^{\circ} \mathrm{C}$ with an annual precipitation of $205 \mathrm{~mm}$ and were formed on rocks of the sandy and sandy-loam composition. The constant mountain and valley winds in the spring and spring-early summer period along with other factors promote the development and deepening of deflation of the chestnut soils in both arable lands and pastures with degraded grass.

The provincial property of the chestnut soils in the Barguzin Depression is a light granulometric composition that was left out of account during the mass plowing of dry steppe landscapes in the 1950s-1960s. At present, the structure of agricultural lands is as follows: arable lands and grasslands account for $65 \%$ and $26 \%$ of 81608 ha in the total area of the chestnut soils, respectively, i.e., the basis for the development of deflation was formed more than 50 years ago.

Humus state. The light granulometric composition with a large share of sand fractions that consist mainly of primary minerals (quartz and field spars) is the major factor that determines the low content of humus and formation of its qualitative composition in the chestnut soils of Transbaikal, including the Barguzin Depression under natural grasses. Thin silt and clay fractions are poor in secondary minerals [11], i.e., the capability to absorb newly formed humic substances is low.

The period of the biological activity decreases in the chestnut soils as a result of their siccation in spring and early summer (up to 70 days); this being the case, the intensity of biological processes in the second half of the vegetation season (July-August) abruptly increases owing to precipitation. The biological activity of the chestnut soils significantly depends on moisture in the vegetation season and varies from very weak (15-25\%) to medium (30-45\%).

Table 1. Biological productivity of grasslands on chestnut soils, $\mathrm{c} / \mathrm{ha}$ of dry weight

\begin{tabular}{|c|c|c|c|c|}
\hline \multirow{2}{*}{ Cenosis } & \multicolumn{3}{|c|}{ Phytomass } & \multirow{2}{*}{$\begin{array}{c}\text { Ratio of aboveground phytomass } \\
\text { to underground one }\end{array}$} \\
\cline { 2 - 4 } & Total & Aboveground & Underground & $1: 33$ \\
\hline $\begin{array}{c}\text { Degraded hard sedge cenosis (with Carex } \\
\text { duriuscula) }\end{array}$ & 95.4 & $\frac{2.8 \pm 0.41}{2.9^{*}}$ & $\frac{92.6 \pm 2.8}{97.1^{*}}$ & $1: 17$ \\
\hline $\begin{array}{c}\text { Tapered meadow-grass feather-grass } \\
\text { cenosis (Stipa krylovii-Poa attenuate) }\end{array}$ & 153.0 & $\frac{8.5 \pm 0.7}{5.6}$ & $\frac{44,5 \pm 14}{94.4}$ & \multirow{2}{|c|}{} \\
\hline
\end{tabular}

Note: $*-\%$ of the total phytomass

Table 2. Composition of humus in chestnut soils under natural pastures, $\%$ of $\mathrm{C}_{\text {total }}$

\begin{tabular}{|c|c|c|c|c|c|c|c|c|c|c|c|c|c|}
\hline \multicolumn{2}{|c|}{$\begin{array}{l}\text { Horizon, } \\
\text { depth, cm }\end{array}$} & $\begin{array}{l}\mathrm{C}_{\text {total }}, \% \\
(\mathrm{n}=3)\end{array}$ & HAs-1 & HAs-2 & HAs-3 & $\begin{array}{c}\text { Sum of } \\
\text { HAs }\end{array}$ & FAs-1a & FAs-1 & FAs-2 & FAs-3 & $\begin{array}{c}\text { Sum of } \\
\text { FAs }\end{array}$ & $\begin{array}{l}\underline{\mathrm{C}}_{\mathrm{ha}} \\
\mathrm{C}_{\mathrm{fa}}\end{array}$ & $\begin{array}{c}\text { Humin, } \\
\%\end{array}$ \\
\hline \multicolumn{14}{|c|}{ Degraded hard sedge cenosis (with Carex duriuscula) } \\
\hline$A_{d}$ & $0-4$ & $0.82 \pm 0.09$ & 3.4 & 14.1 & 15.1 & 32.6 & 3.2 & 4.8 & 12.6 & 7.7 & 28.3 & 1.15 & 39.1 \\
\hline $\mathrm{A}_{1}$ & $7-17$ & $0.81 \pm 0.010$ & 1.1 & 13.7 & 13.0 & 27.8 & 3.8 & 1.9 & 15.1 & 10.4 & 31.2 & 0.89 & 41.0 \\
\hline $\mathrm{B}_{\mathrm{Ca}}$ & $29-37$ & $0.60 \pm 0.007$ & 2.7 & 10.4 & 6.2 & 19.3 & 4.4 & 3.5 & 9.8 & 10.5 & 28.2 & 0.68 & 52.5 \\
\hline \multicolumn{14}{|c|}{ Tapered meadow-grass feather-grass cenosis } \\
\hline$A_{d}$ & $0-3$ & $1.49 \pm 0.02$ & 3.4 & 8.6 & 7.2 & 19.2 & 1.9 & 6.1 & 5.8 & 8.3 & 22.1 & 0.87 & 58.7 \\
\hline \multirow[t]{2}{*}{$\mathrm{A}_{1}$} & $4-11$ & $1.31 \pm 0.02$ & 1.1 & 13.5 & 7.8 & 22.4 & 2.3 & 3.5 & 7.7 & 8.5 & 22.0 & 1.02 & 55.6 \\
\hline & $20-24$ & $0.75 \pm 0.009$ & 2.7 & 12.9 & 13.1 & 28.7 & 3.1 & 4.9 & 11.1 & 10.3 & 29.4 & 0.98 & 41.9 \\
\hline
\end{tabular}


As temperature grows, the mineralization of incoming humus sources strengthens, and humification becomes weaker. This is also promoted by the small quantity of organic matter following the path of humification. Under the conditions of high temperatures, mineralization can take place in the case of low soil moisture. However, the latter impedes the interaction of newly formed humic substances with the mineral part; in connection with this, only the most decomposition-resistant humic substances stably bound with the mineral part of soil are accumulated [12].

The degradation of grassland phytocenoses results in the worsened indicators of the humus state: the decrease in the content and reserves of humus, reduction in the quality of movable humic acids, fulvatization of humus [2, 13]. The deflation processes become stronger in sparse and bald areas of grasslands.
Degraded hard-sedge pasture

$\begin{array}{lllll}0 & 0.4 & 0.8 & 1.2 & 1.6\end{array}$

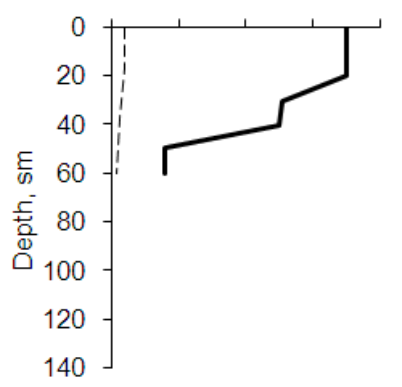

---- content of nitrogen, $\%$
- content of humus, $\%$

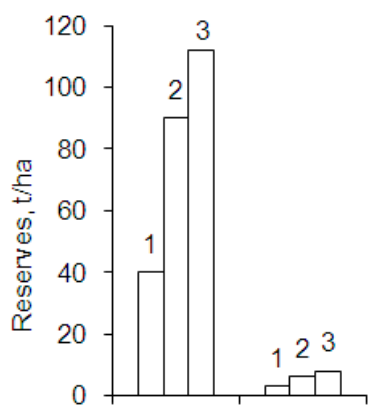

Tapered meadow-grass
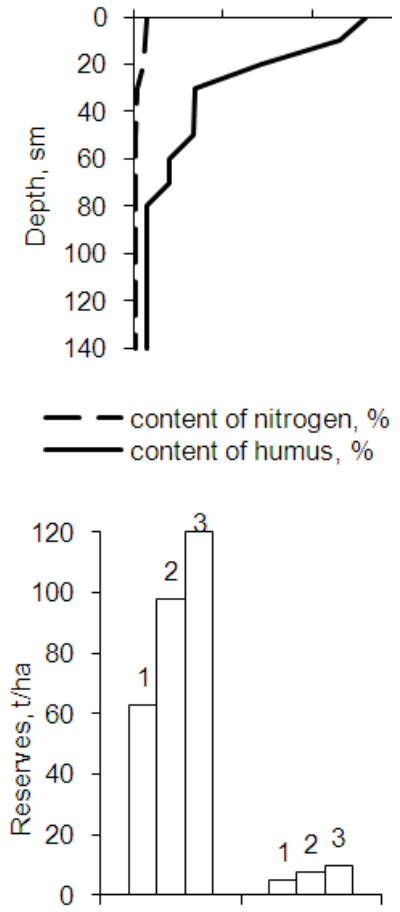
$0 \quad$ pasture

I - Reserves of humus; II - Reserves of nitrogen, t/ha; 1-0-20 cm; 2-0-50 cm; $3-0-100 \mathrm{~cm}$

Figure 2. Content and reserves of humus and nitrogen in chestnut soils under natural pastures.

The biological productivity of dry steppe grasslands in Western Transbaikal is low [14] according to the gradation of N.I. Bazilevich [15]. The intense unsystematic grazing decreases the stocks of the aboveground and underground phytomass (Table 1) and significantly increases their ratio, which does not promote the income of fresh organic matter in the soils under degraded grasslands and damages sod. This leads to the siccation of the upper soil horizons. Due to these negative phenomena, the content and reserves of humus in the $0-20-\mathrm{cm}$ soil layer under hard sedge grassland (with Carex duriuscula C.A. Meyer) is much lower compared to the soil under a grassland with nondamaged grass (with Poa attenuata Trin., Stripa krylovii Roshev.) (Figure 2); however, the existing quantitative changes in the content and reserves of humus have not yet affected its qualitative composition (Table 2). According to the gradation of L.A. Grishina and D.S. Orlov [6], the following indicators for the humus state of the chestnut soils under natural pastures of the basin are typical for this type of soils:

(1) the degree of humification is average;

(2) the content of free humic acids (HAs-1) is very low;

(3) the number of humic acids bound with calcium (HAs-2)

is average and that of fixedly bound acids (HAs-3) is high;

(4) the enrichment of humus with nitrogen $(\mathbf{C : N})$ varies from medium to high.

The development of the deflation processes combined with desertification promotes a significant and sometimes irreversible change in the quantitative and qualitative fertility indicators for the arable chestnut soils of the basin.

Analyzing the data on the content of humus in the chestnut soils of the Upper Kuytun revealed that the diversities of soils in the content of humus formed an ascending series ranging from $0.2 \%$ in loose sand to $2.7 \%$ in light loamy soil. There is a close correlation relationship $(r=0.75)$ between the contents of humus and physical clay, which determines the need to estimate the degree of change in the soil humus state under the influence of the deflation processes for each type taken separately.

Under deflation, the granulometric composition of the chestnut soils strongly changes towards sanding. For some types of soils, a $0-20-\mathrm{cm}$ layer of reserves of humus and humic substances determine the level of degradation of the humus state for each degree of deflation, all other conditions being equal [16]. In the medium deflated soils, the reserves of humus and humic substances decrease with almost equal intensity by a factor of1.2 and 1.3 in light loamy soils and in sandy-loam soils, respectively; HA: FA does not change compared to nondeflated analogs.

In strongly deflated light loamy soils, the reserves of humus and humic acids decreased by a factor of 1.9, those of fulvic acids fell by a factor of1.6, and HA : FA deceased to 0.9 ; in the sandy-loam soils, the reserves of humus, humic acids, and fulvic acids decreased by factors of 2, 3.8., and 2.5, respectively, and HA : FA came to be 0.6. Consequently, the degradation of the humus state of the chestnut soils under deflation and, in particular, sandy-loam types of these soils manifest mainly at the qualitative level. However, the reserves of humic acids decrease much more intensively than those of fulvic acids. As the degree of deflation grows, the reserves of humin decrease relatively gradually.

The same regularities of change in the humus state were ascertained in the soils of the transect that intersect the territory of the Upper Kuytun area (Figure 1, Table 3).

The appearance of constantly growing sand massifs in the location of the chestnut soils is the extreme and irreversible manifestation of deflation. At present, the atmogenic sands of the basin are intensively deflated and gradually move from the north to the south. Strongly deflated soils and sands are dead and represent the centers of expansion of deflation 
to the remaining part of the basin.

In order to decrease the intensity of the deflation processes and interrupt them, a system of measurements is required that must be based on the restoration of natural steppe vegetation, the creation of forest belts, and the fixation of sands with bush plantations. The content and reserves of humus are relatively stabilized in fixed sands, particularly near forest belts (Table 3).

The unique opportunity for the secondary steppification of slopes with nonproductive arable land that is in a fallow state has arisen at the modern stage in Transbaikal. These measures will not only permit the deflation processes in the chestnut soils to be stopped, but will also allow the plant cover to be restored.

Structure of microbial cenoses. According to the study, the structure and activity of microbial cenoses in soils of the dry steppe are determined by their functioning under the conditions of high temperature provision with acute moisture deficit, which causes the development of such forms of microorganisms that are adapted to the unfavorable conditions, namely, spore forming bacteria and ray fungi. In the periods when the combination of temperature and moisture is optimal (July-August), the microbiological processes resulting in the deep mineralization of organic matter in the chestnut soils are noted to be highly intense.

The results of our study of the microbiologica characteristics of chestnut soils under dry steppe grassands that differ in their botanic composition and projective cover have revealed the following:

Microorganisms are very resistant to moisture deficit in soils, which has been proved by their relatively large total number (Table 4).

Table 3. Reserves of humus and humic substances in chestnut soils $(0-20 \mathrm{~cm})$ of degraded pasture and arable land deflated, t/ha

\begin{tabular}{|c|c|c|c|c|c|c|c|c|c|c|c|}
\hline \multirow[t]{2}{*}{ Land } & \multicolumn{2}{|c|}{$\begin{array}{c}\text { Content of } \\
\text { particles }(\mathrm{mm}), \%\end{array}$} & \multirow[t]{2}{*}{$\begin{array}{l}\text { Humus, } \% \\
(\mathrm{n}=5-8)\end{array}$} & \multirow[t]{2}{*}{$\begin{array}{l}\text { Reserves of } \\
\text { humus, } t / h a\end{array}$} & \multicolumn{2}{|c|}{ HAs } & \multicolumn{2}{|c|}{ FAs } & \multicolumn{2}{|c|}{ Humin } & \multirow[t]{2}{*}{ HAs/FAs } \\
\hline & $<0.01$ & $<0.001$ & & & 1 & 2 & 1 & 2 & 1 & 2 & \\
\hline $\begin{array}{c}\text { Grass pasture with regulated } \\
\text { grazing }\end{array}$ & $\begin{array}{l}20.2^{*} \\
24.6\end{array}$ & $12.6 * 14.0$ & $\begin{array}{l}1.87 \pm 0.05 \\
2.36 \pm 0.04\end{array}$ & 64.5 & 20.0 & 31.0 & 18.8 & 29.2 & 25.7 & 39.8 & 1.06 \\
\hline Degraded hard-sedge pasture & $\begin{array}{l}14.8^{*} \\
23.3\end{array}$ & $6.3 * 4.2$ & $\begin{array}{l}1.41 \pm 0.04 \\
1.39 \pm 0.03\end{array}$ & 39.6 & 11.4 & 28.8 & 12.1 & 30.6 & 16.1 & 40.6 & 0.94 \\
\hline \multicolumn{12}{|l|}{ Arable land } \\
\hline Nondeflated & 20.8 & 11.2 & $2.09 \pm 0.07$ & 58.5 & 17.0 & 29.0 & 16.0 & 27.4 & 25.5 & 43.6 & 1.06 \\
\hline Weakly deflated & 18.4 & 10.0 & $1.78 \pm 0.08$ & 49.8 & 13.9 & 27.9 & 15.1 & 30.3 & 20.8 & 41.8 & 0.92 \\
\hline Medium-deflated & 16.8 & 8.2 & $1.46 \pm 0.05$ & 40.9 & 9.1 & 22.2 & 10.5 & 25.7 & 21.3 & 52.1 & 0.87 \\
\hline Strongly deflated & 12.8 & 4.1 & $1.05 \pm 0.05$ & 29.3 & 4.8 & 16.4 & 6.4 & 21.7 & 18.1 & 61.8 & 0.75 \\
\hline Very strongly deflated & 10.0 & 2.6 & $0.85 \pm 0.04$ & 23.8 & 3.1 & 13.0 & 4.8 & 20.2 & 15.9 & 66.8 & 0.64 \\
\hline Loose sand & 4.8 & 0.3 & $0.20 \pm 0.01$ & 7.3 & & & & & & & \\
\hline $\begin{array}{l}\text { Fixed sand (willow } \\
\text { plantations, } 15 \text { years) }\end{array}$ & 7.3 & 1.7 & $0.44 \pm 0.01$ & 13.2 & \multicolumn{7}{|c|}{ Not determined } \\
\hline $\begin{array}{l}\text { Forest belt (pine-tree } \\
\text { plantations, } 30 \text { years) }\end{array}$ & 16.1 & 11.0 & $1.81 \pm 0.04$ & 50.7 & 11.1 & 21.9 & 12.0 & 23.7 & 27.6 & 54.4 & 0.92 \\
\hline
\end{tabular}

Note: $*$ is the $0-3-4 \mathrm{~cm}$ sod layer; column $1: \mathrm{t} / \mathrm{ha}$; column $2: \%$ of humus reserves.

Table 4. Structure of microbial cenoses in deflated chestnut soils

\begin{tabular}{|c|c|c|c|c|c|c|c|c|c|c|}
\hline \multirow{3}{*}{$\begin{array}{l}\text { Soil layer, } \\
\mathrm{cm}\end{array}$} & \multicolumn{2}{|c|}{ BEA } & \multicolumn{2}{|c|}{ SAA } & \multirow[b]{2}{*}{ Fungi } & \multirow{3}{*}{$\begin{array}{l}\text { Total number of } \\
\text { microorganisms }\end{array}$} & \multirow{2}{*}{\multicolumn{2}{|c|}{$\begin{array}{l}\text { Soil enrichment with } \\
\text { microorganisms, } \mathrm{mln} / \mathrm{cm}^{2}\end{array}$}} & \multirow{3}{*}{$\begin{array}{c}\text { Number of } \\
\text { microorganisms } \\
\text { in } 1 \text { g of humus, } \\
\text { mln }\end{array}$} & \multirow{3}{*}{$\frac{\text { SAA }}{\text { BEA }}$} \\
\hline & $\begin{array}{c}\text { Total } \\
\text { number }\end{array}$ & of which & Total & of which & & & & & & \\
\hline & \multicolumn{5}{|c|}{ Thou. CFU/g } & & BEA & SAA & & \\
\hline \multicolumn{11}{|c|}{$\begin{array}{l}\text { Sandy loam } \\
\text { ass hard-sedge pasture }\end{array}$} \\
\hline \multirow[t]{2}{*}{$0-20$} & 1460 & 530 & 2352 & 1050 & 6 & 2516 & $40 * *$ & $64 * *$ & 180 & 1.61 \\
\hline & & & & & Cultivated arable land & able land & & & & \\
\hline $0-20$ & 3079 & 579 & 4233 & 1965 & 14 & 5058 & $89 *$ & $124 *$ & 278 & 1.37 \\
\hline \multicolumn{11}{|c|}{ Medium-deflated arable land } \\
\hline $0-20$ & 1760 & 790 & 2980 & 1360 & 9 & 3129 & $49 * *$ & $83 * *$ & 307 & 1.69 \\
\hline \multicolumn{11}{|c|}{ Strongly deflated arable land } \\
\hline $0-20$ & 1501 & 820 & 2700 & 1257 & 5 & 2763 & $42 * *$ & $55^{* *}$ & 419 & 1.80 \\
\hline \multicolumn{11}{|c|}{$\begin{array}{c}\text { Light loamy } \\
\text { grass pasture with } \mathrm{r}\end{array}$} \\
\hline $0-10$ & 2695 & 962 & 3458 & 1892 & 6 & 4593 & $74 *$ & $101^{*}$ & 190 & 1.28 \\
\hline $10-20$ & 2180 & 684 & 2847 & 1614 & 3 & 3797 & & & 168 & 1.31 \\
\hline $20-30$ & 415 & 144 & 952 & 702 & 1 & 1118 & & & 115 & 2.29 \\
\hline \multicolumn{11}{|c|}{ Degraded hard-sedge pasture } \\
\hline $0-10$ & 1860 & 896 & 2877 & 1312 & 3 & 3175 & $57 *$ & $82 * *$ & 227 & 1.55 \\
\hline $10-20$ & 1506 & 626 & 2342 & 900 & 1 & 2407 & & & 178 & 1.56 \\
\hline $20-30$ & 710 & 182 & 1265 & 405 & 0.3 & 1115 & & & 108 & 1.78 \\
\hline
\end{tabular}

Note: $*$ - middle, $* *$ - poor 
The near-surface concentration in the $0-10-\mathrm{cm}$ soil layer is typical for the microbiological profile. As the depth increases, the number of microorganisms abruptly (by a factor of 2.8 and 4.1) decreases, in particular the number of bacteria.

The share of xerophyte forms is significant in the composition of microbial cenoses, i.e., $25.6-48.2 \%$ of spore-forming bacteria and $37.4-42.5 \%$ of ray fungi. In soils under degraded grass, enrichment with microorganisms decreases from the medium to low level.

The accumulation of microorganism biomass depends on the content of organic matter in the soil, the density of roots, and the intensity of their secretions; they vary within $0.27-4.8 \%$ of the total soil carbon [17]. According to other estimates, soil microbial biomass accounts for $3-10 \%$ of organic carbon [18]. The content of microbial biomass in soil is sensitive to anthropogenic effects and environmental factors; correspondingly reflects the short-term dynamics of soil organic matter and its spatial variability; and is a reliable indicator of qualitative changes $[19,20]$.

The reserves of microorganism biomass in the root inhabited soil layer $(0-50 \mathrm{~cm})$ correlate with the ecological conditions of their functioning and are determined by the influence of the environment-forming factor, i.e., the cyclicity of precipitation, short duration of the biologically active period, the confinement of underground phytomass to the surface soil horizons, income of fresh organic matter, etc. The greatest microbial mass (1.26-1.50 t/ha of dry weight) was revealed in chestnut soils under nondamaged grasses. The degradation of the plant cover in dry steppe grasslands results in the worsened moisture provision and reduced sizes of underground phytomass, which is why the lowest reserves of microbial mass (1.06 t/ha) were noted under degraded hard-sedge cenosis.

In the arable chestnut soils of Transbaikal, the share of the clay fraction and quantity of humus in it decrease first [21]. The development of deflation processes in the arable chestnut soils leads to the significant decrease in the share of clay and strengthens soil sanding (Table 3). It was ascertained that the most easily decomposed carbon compounds were contained [22] in the sand soil fraction. In general, the decomposability of clay and soil organic matter occupies an intermediate position between the sand and silt fractions; moreover, the organic components of the silt fraction are the most resistant. However, the respiration activity is related to the clay, silt, and sand fractions by $58-73,21-55$, and $6-19 \%$, respectively. Consequently, when the chestnut soils are sanded, their biological activity changes. The reconstruction of a microbe cenosis is accompanied by a reduction in the total number of microorganisms, particularly fungi, and by the decrease in biogenicity (Table 4). Simultaneously, the share of the xerophyte complex (ray fungi and spore-forming bacteria) grows. For example, if the share of spore-forming bacteria and ray fungi in a cultivated arable land is 18.8 and $38.8 \%$, respectively; then, their share participation in medium-deflated and strongly-deflated differences grows up to 44.9 and $43.5 \%$ and 54.6 and $45.5 \%$, respectively. The enrichment of deflated arable chestnut soils with microorganisms using mineral and organic nutrient sources is poor and lower than in cultivated arable land by a factor of 1.8-2.1 and 1.5-2.3, respectively. This is determined by the low provision of soils with mobile nutrients and easily decomposed organic material. The reserves of microbial mass in deflated soils are $0.55-0.76 \mathrm{t} / \mathrm{ha}$.

These changes determine the development of the mineralization processes in soil, which is proved by the growth in the values of the mineralization coefficient, i.e., the ratio of microorganisms grown in BEA to the number of bacteria in SAA, as well as growth in the number of microorganisms in $1 \mathrm{~g}$ of humus.

\section{Conclusion}

The bioproductivity of steppe grasslands depending on the location of relief elements, botanic composition, degree of grass degradation, and moisture provision in the vegetation season is estimated to be low-yield. Underground phytomass accounts for the major share in the total reserves, i.e., 91.6-97.3\%. The reserves of both aboveground and underground phytomass decrease in degraded grasses, and the value of their ratio increases.

The reserves of humus and its composition in the chestnut soils of the Barguzin Depression reflect the properties of humus formation depending on the dominant factors of soil formation. Their formation on sandy and sandy-loam alluvia and functioning under the unfavorable natural and climatic conditions do not promote the accumulation of humus and ecological resistance of soils to anthropogenic loads.

The decrease in the reserves of humus and its components takes place in deflated soils. The losses of humic acids in soil determine the development of fulvatization of humus that takes the humate-fulvate or fulvate type. The reserves of humin decrease to a lesser extent, but the dependence of their decrease on the degree of soil deflation is also evident. The dehumification and sanding of deflated soils results in an abrupt decrease in their fertility, which forms the basis for the development of moving sands.

The formation of specific microbial cenoses with a relatively large number of microorganisms represented mainly by the xerophyte forms is determined by the fact that the chestnut soils are under the cryoarid conditions for a long time during a year and by the specific chemical composition of organic matter coming into soil (the root litter). The biological activity and accumulation of microbial mass grow in the short periods when the combination of temperature and moisture (July-August) is optimal.

The degradation of the plant cover and development of deflation cause the impoverishment with microorganisms and decrease in microbial mass and subsequent xerophytization of a microbial cenosis. 


\section{REFERENCES}

[1] V.N. Sheptukhov, T.V. Reshetina, P.N. Berezin, I.I. Karmanov, B.V. Vinogradov and B.A. Zimovets. On Improvement of Evaluation of Processes of Soil Degradation, Pochvovedenie, No. 7, 799-805, 1997.

[2] A.B. Rozanov and B.G. Rozanov. Ecological Studies of Anthropogenic Changes in Soils, Itogi Nauki i Tekhniki, 156, 1990.

[3] G.F. Koposov, A.A. Gladkov, I.Y. Slesarev, N.N. Naplekova, and B.M. Klenov, Chestnut Soils, in Pochvy Barguzinskoi kotloviny (Soils of Barguzin Hollow), Nauka, Novosibirsk, 55-83, 1983.

[4] Agrochemical methods of soil studies, Nauka, Moscow, 656, 1975.

[5] V.G. Mineev. Workshop on Agrochemistry, Moscow State University, Moscow, 689, 2001.

[6] L.A. Grishina, Orlov D.S. A system of indicators of soil humus condition, Problems of soil science, Nauka, Moscow, 42-48, 1978.

[7] G.M. Zenova, A.L. Stepanov, A. A. Likhachev, N.A. Manucharov. Workshop on soil biology, Moscow state University, Moscow, 120, 2002.

[8] A.I. Zrazhevskii, A.I. Seryi and V.A. Andrienko. Biomass of Life Matter of Soil as a Source of Plant Nutrition, in Problemy i metody biologicheskoi diagnostiki i indikatsii pochv (Problems and Methods of Biological Diagnostic and Indication of Soils), Moscow, 212-222, 1976.

[9] D.G. Zvyagintsev. Biological Activity of Soils and a Scale for Evaluation of Several Indexes, Pochvovedenie, No. 6, 48-54, 1978.

[10] B.A. Dospekhov, Metodika polevogo opyta (s osnovami statisticheskoi obrabotki rezul'tatov issledovanii) (A Method of Field Experience (Including Fundamental Statistic Research Data Delivery), Kolos, Moscow, 416, 1979.

[11] T.V. Abidueva, T.A. Sokolova, Glinistye mineraly i kaliinoe sostoyanie stepnykh pochv Zapadnogo Zabaikal'ya (Loamy Minerals and Potash Status of Steppe Soils of Western Transbaikalia), Izd. SO RAN, Novosibirsk, 100, 2005.

[12] N.F. Ganzhara, V.I. Kiryushin, Alteration of Humus Status in Soils During Transformation of Natural Phytocenosises to
Agrocenosises, in Kontseptsiya optimizatsii rezhima organicheskogo veshchestva pochv $\mathrm{v}$ agrolandshaftakh (A Concept of Optimization of Regime of Soil Organic Matter in Agricultural Landscapes), Izd. MSKhA, Moscow, 39-51, 1993.

[13] Ch.S. Kyrgys. Carbon Critical in the System "Plant-Soil" in Steppes of Ubsunursk Hollow, Avtoref. hand. biol. nauk, Tomsk state University, Tomsk, 24, 2004.

[14] M.G. Merkusheva, L.L. Ubugunov and V.M. Korsunov. Bioproduktivnost' pochv senokosov i pastbishch sukhostepnoi zony Zabaikal'ya (Soil Bioproductivity in Haymakings and Pastures of Dry Zone of Transbaikalia), Izd. BNTs SO RAN, Ulan-Ude, 515, 2006.

[15] N.I. Bazilevich. Biologicheskaya produktivnost' ekosistem Severnoi Evrazii (Biological Productivity of Ecosystems of North Eurasia), Nauka, Moscow, 293, 1993.

[16] M.G. Merkusheva and T.S. Borisova. Humus Status of Deflected Chestnut Soils of Barguzin Hollow (Western Transbaikalia), in Tez. dokl. III s"ezda DOP (The III Congress of DOP, Abstract of Papers), Moscow, Vol. 2, 320-321, 2000 .

[17] R.L. Teit. Organicheskoe veshchestvo pochv (Organic Matter of Soils), Mir, Moscow, 399, 1991.

[18] V.M. Semenov, L.A. Ivannikova and T.V. Kuznetsova. Structure-Functional Status of Organic Substance in Soil, in Pochvennye protsessy i prostranstvenno-vremennaya organizatsiya pochv (Soil Processes and Space-Time Structure of Soils), Nauka, Moscow, 230-247, 2006.

[19] M.C. Scholes, D. Powlson and G. Tian. Input Control of Organic Matter Dynamics, Geoderma, Vol. 79, 25-27, 1997.

[20] M. Von Lutzow, J. Leifeld, M. Kainz, I. Kogel-Knabner, J.C. Munch. Indications for Soil Organic Matter Quality in Soils Under Different Management, Geoderma, Vol. 105, 243-258, 2002.

[21] L.L. Ubugunov, V.I. Ubugunova, and M.G. Merkusheva. Concentration of Humus and Nitrogen in Grain-Size Fractions of Chestnut Soils of Western Transbaikalia, Pochvovedenie, No. 1, 80-86, 1990.

[22] Christensen, B.T., Decomposability of Organic Matter in Particle Size Fractions from Field Soils with Straw Incorporation, Soil Biol. Bioch., No. 9, 429-435, 1987. 